Original Paper

\title{
Peningkatan Kapasitas Masyarakat dalam Pengolahan Sampah Sebagai Kompos di Kelurahan Dasan Geres Lombok Timur
}

\author{
Arben Virgota ${ }^{1 *}$, Baiq Farista ${ }^{1}$, Dining Aidil Candri ${ }^{1}$, Hilman Ahyadi ${ }^{1}$, Ahmad Jupri ${ }^{1}$ \\ ${ }^{1}$ Program Studi Biologi, Fakultas MIPA, Universitas Mataram, Lombok, Indonesia.
}

DOI: $10.29303 /$ jpmpi.v2i2.376

Sitasi: Virgota, A., Farista, B., Candri, D., Ahyadi, H., \& Jupri, A. (2020). Peningkatan Kapasitas Masyarakat dalam Pengolahan Sampah Sebagai Kompos di Kelurahan Dasan Geres Lombok Timur. Jurnal Pengabdian Magister Pendidikan IPA, 2(2). doi:https://doi.org/10.29303/jpmpi.v2i2.376

*Corresponding

Author: Arben Virgota, Program Studi Biologi, Fakultas MIPA,

Universitas Mataram,

Lombok, Indonesia;

Email:

arben@unram.ac.id

\begin{abstract}
Tujuan dari pengabdian pada masyarakat ini adalah mengolah sampah menjadi kompos agar dimanfaatkan sebagai pupuk organik dan memberikan nilai ekonomis sampah kota organik melalui penjualan kompos yang dihasilkan. Metode yang digunakan dalam kegiatan ini adalah: Ceramah, diskusi, pelatihan, praktek dan pendampingan. Ceramah dan diskusi dilaksanakan untuk penyampaian materi secara langsung pada masyarakat oleh narasumber yang kompeten dibidangnya sesuai kebutuhan. Pelatihan dilakukan untuk meningkatkan pengetahuan dan ketrampilan tentang: Pengolahan sampah organik untuk pembuatan kompos/pupuk organik, dan pemanfaatan kompos untuk media budidaya taman vertikutur. Pelatihan dan Praktek dilaksanakan untuk ketrampilan masyarakat : Pengolahan sampah organik sebagai bahan dasar pembuatan kompos, sehingga masyarakat dapat membuat pupuk organik sendiri. Pendampingan dilaksanakan dalam rangka memotivasi masyarakat untuk selalu menjaga kebersihan lingkungan, memanfaatkan sampah organik sebagai kompos, sehingga lingkungan permukiman menjadi bersih dan indah. Simpulan dari program pengabdian ini adalah masyarakat Dasan Geres, Lombok Timur dapat mengolah sampah organik untuk dijadikan sebagai pupuk kompos. Pengolahan sampah sebagai kompos sangat mudah dilakukan oleh masyarakat secara mandiri, tidak membutuhkan biaya yang besar, namun sangat mendukung upaya menjaga kebersihan lingkungan. Komitmen masyarakat untuk melanjutkan upaya pengembangan program ini sangat memungkinkan untuk mewujudkan Dasan Geres yang sehat dan indah di kemudian hari.
\end{abstract}

Keywords: Kapasitas Masyarakat; Pengelolaan Sampah; Kompos.

\section{Pendahuluan}

Kelurahan Geres dikenal sebagai desa pertambangan karena masyarakat yang ada di Kelurahan Geres dominan bermata pencaharian sebagai buruh tambang batu apung dan buruh tambang pasir. Tambang pasir dibagi menjadi dua yaitu tambang pasir kali dan tambang pasir pantai (pasir besi). Warga kelurahan Geres banyak berkerja ditambang yang berada di Ijobalit dan di Geres Lauq. Kelurahan Geres juga mempunyai sumber daya alam seperti tanaman bambu dan singkong. Bambu dan singkong tersebut dibiarkan begitu saja dan adapula yang menjual sumber daya alam tersebut tanpa diolah terlebih dahulu, sehingga masayarakat belum mampu memanfaatkan hasil dari sumber daya alam yang dimiliki secara maksimal.

Lingkungan kelurahan Geres juga terdapat banyak sampah. Sampah ini merupakan salah satu permasalahan yang ada di kelurahan Geres. Sampah merupakan material sisa yang tidak diinginkan. Sampah menjadi permasalahan sulit ketika pertumbuhan penduduk semakin besar. Semakin banyak jumlah penduduk maka semakin banyak jumlah sampah rumah tangga yang dibuang ke lingkungan. Sampah akan menjadi masalah ketika tidak terkelola dengan baik. Sampah yang tidak terbuang ke Tempat Pembuangan Akhir (TPA) akan menumpuk dan menjadi timbulan sampah (Megaiswari 2016). Dengan demikian dibutuhkan pengelolaan sampah dengan baik. Pengelolaan 
sampah merupakan tanggung jawab semua pihak. Menurut Peraturan Pemerintah Republik Indonesia Nomor 81 tahun 2012 tentang Pengelolaan Sampah Rumah Tangga dan Sampah Sejenis Sampah Rumah Tangga, pengelolaan sampah bertujuan untuk menjaga kelestarian fungsi lingkungan hidup dan kesehatan masyarakat juga menjadikan sampah sebagai sumberdaya. Salah satu tantangan yang dihadapi oleh pengelola perkotaan adalah penanganan permasalahan sampah (Puspitawati dan Rahdriawan 2012).

Menurut Subekti (2009) sampah adalah limbah yang bersifat padat terdiri dari zat organik maupun zat anorganik yang dianggap tidak berguna lagi dan harus dikelola agar tidak membahayakan lingkungan dan melindungi investasi pembangunan. Sampah padat adalah semua barang sisa yang ditimbulkan dari aktivitas manusia dan binatang yang secara normal padat dan dibuang ketika tidak dikehendaki lagi (Tchobanoglous 1993). Menurut Wibowo dan Djajawinata (2002) dari total sampah kota yang dihasilkan, sekitar 53,3\% tidak tertangani dengan baik. Purwasasmita (1989) melaporkan bahwa sekitar 70-80\% sampah kota merupakan bahan organik.

Timbunan sampah terus menumpuk karena sulit terurai dengan tanah dan dapat menimbulkan pencemaran tanah. Tidak hanya itu, Timbunan sampah yang tidak termanfaatkan tersebut dapat menimbulkan bau menyengat dan dapat mengganggu kesehatan dan kebersihan lingkungan masyarakat kelurahan Geres. Dengan demikian, perlu adanya penanganan yang tepat agar sampah organik kota dapat berkurang. Salah satu cara yang dapat dilakukan adalah dengan memanfaatkan kembali sampah organik bahan baku kompos.

\section{Metode Pelaksanaan}

Metode yang digunakan dalam kegiatan ini adalah: Ceramah, diskusi, pelatihan, praktek dan pendampingan. Ceramah dan diskusi dilaksanakan untuk penyampaian materi secara langsung pada masyarakat oleh narasumber yang kompeten dibidangnya sesuai kebutuhan. Pelatihan dilakukan untuk meningkatkan pengetahuan dan ketrampilan tentang: Pengolahan sampah organik untuk pembuatan kompos/pupuk organik, dan pemanfaatan kompos untuk media budidaya taman vertikutur.

Pelatihan dan Praktek dilaksanakan untuk ketrampilan masyarakat : Pengolahan sampah organik sebagai bahan dasar pembuatan kompos, sehingga masyarakat dapat membuat pupuk organik sendiri. Pendampingan dilaksanakan dalam rangka memotivasi masyarakat untuk selalu menjaga kebersihan lingkungan, memanfaatkan sampah organik sebagai kompos, sehingga lingkungan permukiman menjadi bersih dan indah.

Adapun tahapan kegiatan pengabdian pada masyarakat ini adalah sebagai berikut: 1) Sosialisasi dan koordinasi dengan semua pihak terkait, kegiatan ini bertujuan untuk mengkomunikasikan rencana kegiatan seetta legalisasi kegiatan. 2) Membuat rumah kompos, pengadaan alat \& bahan, tahapan ini dimaksudkan untuk mempersiapkan peralatan dan bahan yang dibutuhkan dalam kegiatan pengolahan sampah menjadi kompos. 3) Memilahan sampah organik dan non organik dan pelatihan pembuatan pupuk kompos. 4) Mengedukasi para penduduk Kelurahan dasan Geres untuk membuang sampah pada tempatnya. 5) Mengolahan sampah organik secara rutin menjadi pupuk kompos dan pemasarannya

\section{Hasil dan Pembahasan}

\section{Pencapaian Tujuan}

Hasil kegiatan pengabdian ini ditinjau dari pencapaian tujuan kegiatan sangat berhasil hal ini terlihat dari tingginya respon dan kehadiran peserta saat mengikuti kegiatan ini. Selama proses berlangsungnya kegiatan peserta sangat antusias dan aktif terlibat mulai dari awal hingga akhir kegiatan, peserta terlibat penuh dan proses tanya jawab sangat intens dilakukan.

Kegiatan pengabdian diawali dengan sosialisai pengolahan sampah sebagai bahan baku kompos dan pemanfaatan kompos sebagai media budidaya sayuran di lahan pekarangan penduduk. 
Dan selanjutnya dilakukan demstrasi pengolahan sampah menjadi kompos.

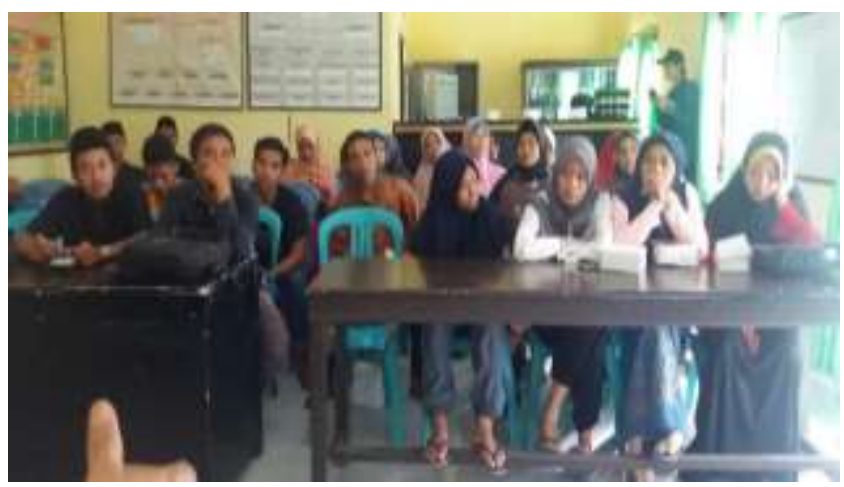

Gambar 1. Peserta Sosialisasi Pengolahan Sampah Organik di Dasan Geres Lombok Timur
Gambar 2. Kegiatan Sosialisasi Pengolahan Sampah Organik di Dasan Geres, Lombok Timur

Pada kegiatan ini dilakukan juga sosialiasi pemanfaatan sampah anorganik, lalu menampilkan display atau sampel produk yang kami buat dari sampah plastik yaitu ecobrick. Ecobricks adalah pengolahan sampah plastik menjadi material ramah lingkungan. Ini merupakan upaya untuk mengurangi menumpuknya sampah plastik. Material ramah lingkungan tersebut dibuat dengan memasukkan dan memadatkan sampah plastik yang sudah bersih dan kering ke dalam botol plastik bekas serta menggunakan tongkat kecil untuk memadatkan sampah plastik didalam botol tersebut.

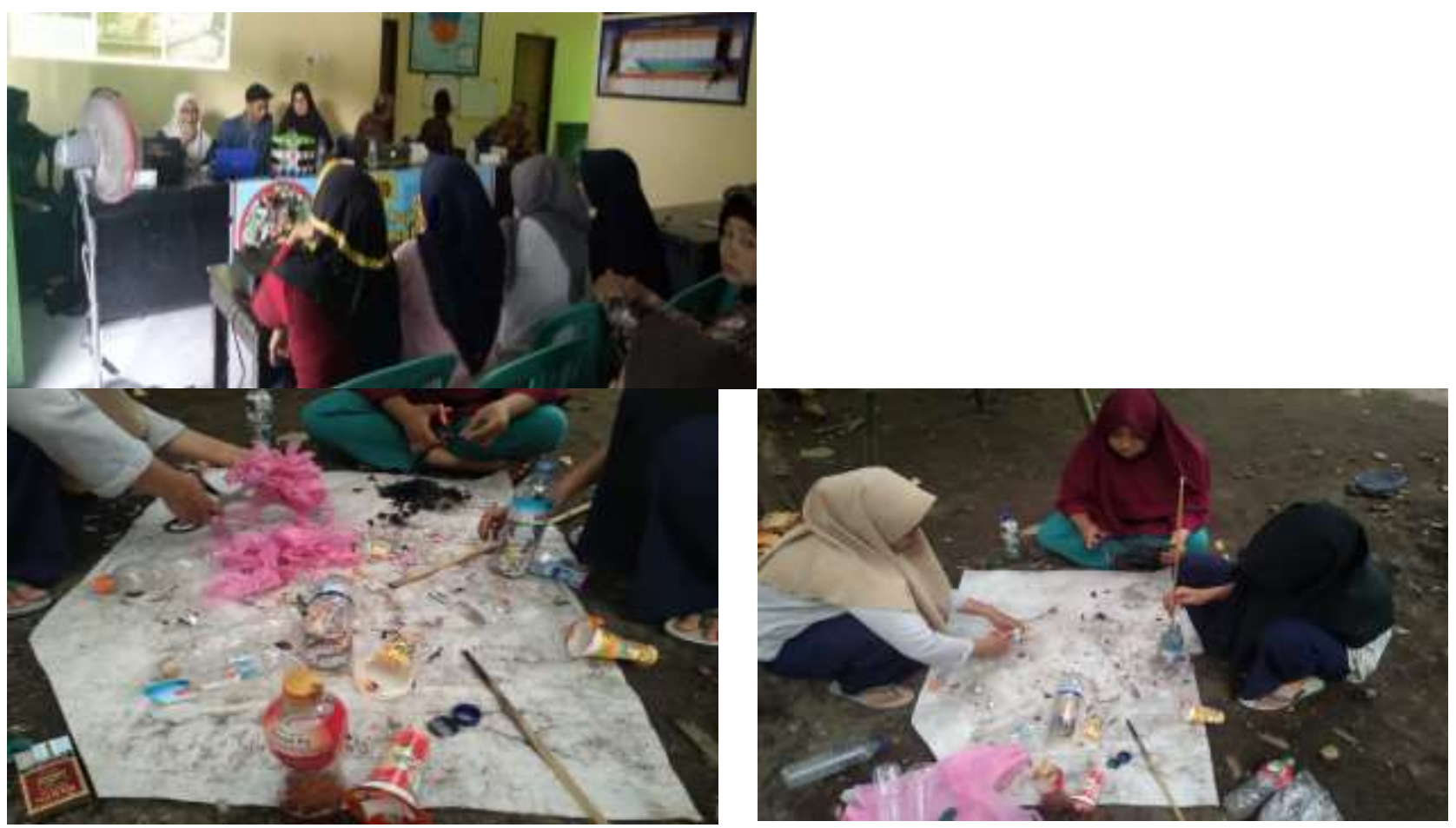

Gambar 3. Proses pembuatan Ecobricks dalam upaya pemanfaatan sampah anorganik di Dasan Geres, Lombok Timur

\section{Pencapaian Sasaran}

Disadari bahwa permasalahan sampah bukan hanya menggangu estetika lingkungan, namun juga sangat potensial mengganggu kesehatan masyarakat. Menurut peserta, harus segera ditangani karena tumpukan-tumpukan sampah di sepanjang jalan kampung telah mengganggu pemandangan dan menimbulkan bau yang kurang sedap. Masyarakat sangat tertarik untuk bisa mengolah sampah tersebut menjadi bahan yang lebih bermanfaat dan berharap sampah tidak lagi menumpuk, sehingga lingkungan menjadi bersih dan indah.

Demonstrasi pengolahan sampah menjadi kompos memanfaatkan sampah-sampah organik yang berasal dari sisa konsumsi rumahtangga seperti sisa makanan, sayur-sayuran, daun kering dan juga kotoran ternak. Dalam pembuatan pupuk kompos, hal pertama yang harus dilakukan adalah menyiapkan tempat atau wadah serta alat dan bahan yang diperlukan. Wadah yang digunakan bermacam, mulai dari wadah yang tebuat dari plastik, kayu maupun bambu. Selain itu ukurannya 
pun bermacam, semakin besar wadahnya akan semakin banyak sampah yang bisa tertampung. Wadah yang dipergunakan menyerupai tempat sampah, hanya pada wadah ini bagian bawahnya tidak beralas. Pada pelatihan ini kami membuat wadah dengan bahan utama papan bekas dan bambu bekas. Tujuanlah ialah selain menghemat biaya, juga merupakan upaya untuk meminimalisir jumlah sampah yang ada. Selain itu, bahan dari pupuk kompos yang kami gunakan adalah limbah sampah yang basah yang meliputi kulit nanas, kotoran sapi dan kambing, sedangkan limbah sampah kering berupa daun kering dan serbu gergaji. Selanjutnya Kompos yang dihasilkan digunakan pada usaha bertanam sayuran di pekarangan dengan teknik vertikultur dan hidroponik.
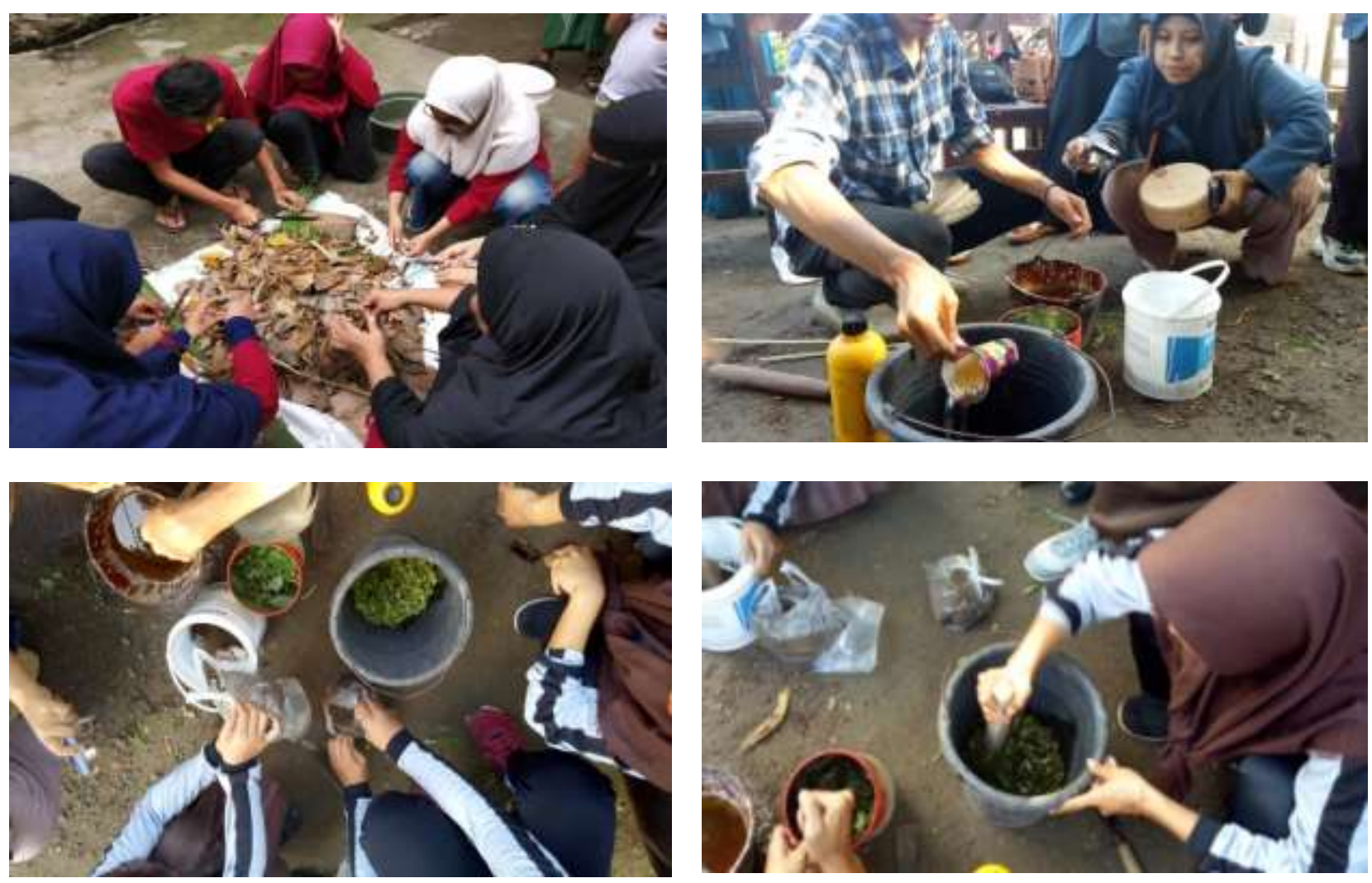

Gambar 4. Proses pembuatan kompos

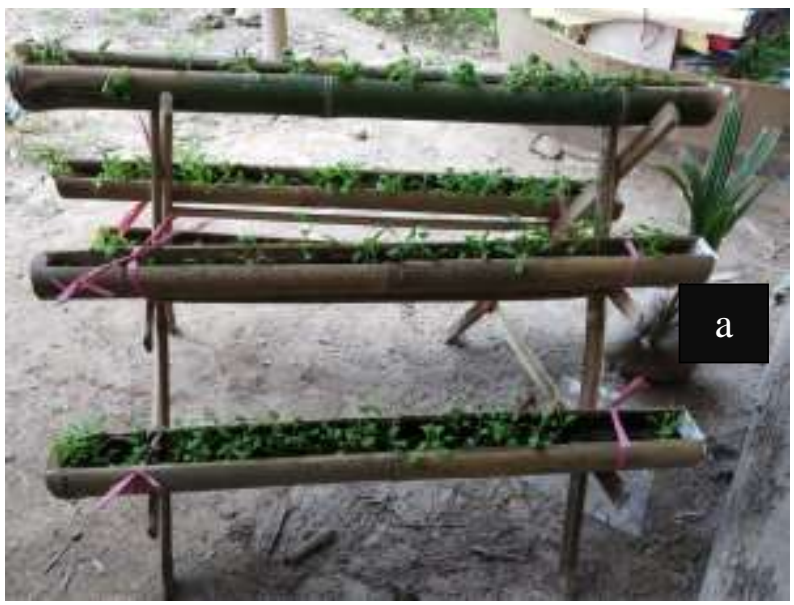

Gambar 5. Bertanam sayuran organik di pekarangan
Kegiatan pengabdian masyarakat dalam bentuk sosialisasi dan pelatihan inovasi vertikultur dalam pemanfaatan hasil pengolahan sampah rumah tangga di Dasan Geres, Lombok Timur ini diikuti sekitar 20 orang peserta yang berasal dari pemuda dan ibu rumah tangga di Dasan Geres.

Secara umum dapat dinyatakan bahwa kegiatan ini mencapai target sasaran dengan baik. Dilihat dari segi jumlah yang sangat cukup sehingga seluruh peserta dapat terlibat langsung selama proses pelatihan. Keragaman usia dan latar belakang peserta mulai dari pemuda karang taruna, remaja mesjid dan ibu rumah tangga, yang ingin mengurangi tumpukan sampah yang adan dan memanfaatkannya sebagai kompos. Dan selanjutnya, kompos yang dihasilkan dapat 
dimanfaatkan dalam usaha budidaya sayuran di lahan pekarangan dengan teknik vertikultur.

\section{Analisa}

Faktor Penghambat.

Kendala yang ditemukan pada kegiatan ini adalah kurangnya rasa kepedulian atau kesadaran sebagian masyarakat Kelurahan Geres akan lingkungan yang bersih dan sehat.

Faktor Pendorong.

Keinginan yang tinggi dari peserta untuk mencoba semua materi yang diajarkan untuk mendapatkan manfaat ekonomis dari pengolahan sampah.

\section{Kesimpulan}

Simpulan dari program pengabdian ini adalah masyarakat Dasan Geres, Lombok Timur dapat mengolah sampah organik untuk dijadikan sebagai pupuk kompos. Pengolahan sampah sebagai kompos sangat mudah dilakukan oleh masyarakat secara mandiri, tidak membutuhkan biaya yang besar, namun sangat mendukung upaya menjaga kebersihan lingkungan. Komitmen masyarakat untuk melanjutkan upaya pengembangan program ini sangat memungkinkan untuk mewujudkan Dasan Geres yang sehat dan indah di kemudian hari.

\section{Daftar Pustaka}

Dwiyanto BM. 2011. Model Peningkatan Partisipasi Masyarakat dan Penguatan Sinergi dalam Pengelolaan Sampah Perkotaan. Jurnal Ekonomi Pembangunan. 2(2011):239-256.

Puspitawati Y, Rahdriawan M. 2012. Kajian Pengelolaan Sampah Berbasis Masyarakat dengan Konsep 3R (Reduce, Reuse, Recycle) di Kelurahan Larangan Kota Cirebon. Pembangunan Wilayah dan Kota. 8 (4): 349-359.

Saptoadi, Harwin. 2001. Utilization Of Organic Matter From Municipal Solid Waste In Compost Industries.Jurnal Manusia Dan Lingkungan, Vol.VIII, Desember, Hal 119 129.
Subekti S. 2009. Pengelolaan Sampah Rumah Tangga 3R Berbasis Masyarakat. [Internet] [Diunduh pada 20 Desember 2017]. Tersedia pada

http://www.scribd.com/doc/19229978/tulisan -bektihadini. 